\title{
Study on the Distribution of ${ }^{131}$ I Labeled Toxohormone
}

\author{
Kijuro Obara, Shigeru Ono, Fusao Nishizuka \\ and Masao Hatano \\ Department of Biochemistry (Prof. K. Obara), \\ Iwate Medical College, Morioka
}

\begin{abstract}
The distribution rate of sodium iodide $\left(\mathrm{Na}^{131} \mathrm{I}\right)$ and toxohormone labeled with $\mathrm{Na}^{131} \mathrm{I}$ in rats under various experimental conditions was described.

Toxohormone extracted from the cancer tissue of the stomach removed by surgical operation exhibited a remarkable inhibitory effect on liver catalase.

Compared with the distribution of $\mathrm{Na}^{131} \mathrm{I}$ in the liver and spleen of the normal rats, that of $\mathrm{Na}^{131} \mathrm{I}$ labeled toxohormone in the above organs was found to be characteristically decreased. It was also decreased in the liver of splenectomized rats. The distribution of $\mathrm{Na}^{131} \mathrm{I}$ was reduced in the liver and spleen of rats, which had been treated with toxohormone for successive two days. It was also decreased in the above organs of rats with moderate liver impairment.

The function of the reticuloendothelial system in the liver and spleen of the tumor bearing organisms was regarded to be important in the inactivation of toxohormone released from tumor tissue.

The distribution rate of labeled toxohormone in the alimentary canal, especially in the stomach, was found to be increased after intraperitoneal administration of the substance. The results were interpreted in association with the excretion of $\mathrm{Na}^{131} \mathrm{I}$ labeled toxohormone from the alimentary canal.
\end{abstract}

Toxohormone is a heat-stable polypeptide extracted by Nakahara ${ }^{1}$ in 1948 from cancer tissue as an inhibiting factor of catalase activity of the liver. Toxohormone has been widely used in the investigation of biochemical changes in the host bearing tumor. It is reasonable to assume that a decreased metabolic activity in cachexia which appears in the final stage of cancer patients is a result of disturbed homeostasis by a toxin or toxins released from cancer tissues. The present study was performed to investigate the distribution rate of toxohormone labeled with $\mathrm{Na}^{131} \mathrm{I}$ in albino rats with liver impairment, splenectomized or treated with toxohormone.

\section{METHODS}

Toxohormone was extracted from the cancer tissue of the stomach which had been obtained by surgical operation, by using the extraction method for

Received for publication, March 3, 1966. 
corticotropine. $^{2}$ The catalase activity of liver homogenate of the mouse was determined by $\mathrm{KMnO}_{4}$ titration method. The results obtained by this method showed a remarkable inhibition of catalase activity in proportion to the dose of toxohormone administered intraperitoneally.

Toxohormone was labeled with $\mathrm{Na}^{131} \mathrm{I}$ according to the procedure described by $\mathrm{F}_{0 \mathrm{ss}}{ }^{3,4}$ for protein solution of low concentration. The iodination procedure was carried out at $0^{\circ} \mathrm{C}$. To $0.6 \mathrm{ml}$ of $\mathrm{Na}^{131} \mathrm{I}$ solution of $300 \mathrm{Ci}$ were added $0.1 \mathrm{ml}$ of $9 \% \mathrm{NaCl}$ solution, $0.01 \mathrm{ml}$ of $1 \% \mathrm{KI}$ solution, $0.01 \mathrm{ml}$ of $1 \% \mathrm{KIO}_{3}$ solution and $0.05 \mathrm{ml}$ of $0.1 \mathrm{~N} \mathrm{HCl}$. Five minutes after mixing, $0.05 \mathrm{ml}$ of $0.1 \mathrm{~N} \mathrm{NaOH}$ and $0.2 \mathrm{ml}$ of $0.1 \mathrm{M} \mathrm{NH}_{3}-\mathrm{NH}_{4} \mathrm{Cl}$ buffer $\mathrm{pH} 8.6$ were added. To $0.2 \mathrm{ml}$ of toxohormone solution adjusted to $\mathrm{pH} 8.6$ were added rapidly $0.2 \mathrm{ml}$ of the above mentioned iodine solution, and the two solutions are thoroughly mixed. Ten seconds later $0.1 \mathrm{ml}$ of $0.1 \mathrm{~N}$ solution of $\mathrm{Na}_{2} \mathrm{~S}_{2} \mathrm{O}_{3}$ was added and the mixture was well shaken.

Unless otherwise stated, the rats were sacrificed by decapitation usually one hour after the administration of $\mathrm{Na}^{131} \mathrm{I}$ or toxohormone labeled with $\mathrm{Na}^{131} \mathrm{I}$; the liver, kidney, spleen, small intestine, large intestine, lung, brain, heart, pituitary gland, thyroid gland, pancreas, adrenals, testis and large omentum were removed. These organs were washed with saline solution, blotted and weighed out quickly and they were made ash by burning, and the distribution rates of $\mathrm{Na}^{131} \mathrm{I}$ and of toxohormone labeled with $\mathrm{Na}^{131} \mathrm{I}$ were expressed as percentages of radioactivity per minute per gram of each organ, which was counted by a Geiger-Müller counter.

Male albino rats of Wistar strain weighing about $150 \mathrm{~g}$ were used as experimental animals. A moderate liver impairment was produced by intraperitoneal administration of $1 \mathrm{ml} / \mathrm{kg}$ of $20 \% \mathrm{CCl}_{4}$ in olive oil, and $\mathrm{Na}^{131} \mathrm{I}$ was administered intraperitoneally on the $3 \mathrm{rd}$ day of carbon tetrachloride administration.

The effect of toxohormone on the distribution rates of $\mathrm{Na}^{131} \mathrm{I}$ in various organs of normal rats was investigated; the animals had been treated with toxohormone for successive two days before $\mathrm{Na}^{131} \mathrm{I}$ was intraperitoneally administered.

The time course of a change in the distribution rate of $\mathrm{Na}^{131} \mathrm{I}$ labeled toxohormone in various organs of normal rats was studied by sampling in 30 $\min$ and $60 \mathrm{~min}$ after intraperitoneal administration.

The spleen was removed by surgical operation to investigate an influence of splenectomy on the distribution rate of $\mathrm{Na}^{131} \mathrm{I}$ labeled toxohormone in the various organs.

\section{RESULTS}

The results obtained in the normal rats to which only $\mathrm{Na}^{131} \mathrm{I}$ was intraperitoneally administered are shown in Fig. 1. The distribution rates in the brain, hypophysis, heart, pancreas, adrenals, omentum and testis were found to be very low. Therefore, distribution of radioactive iodine in various organs except 


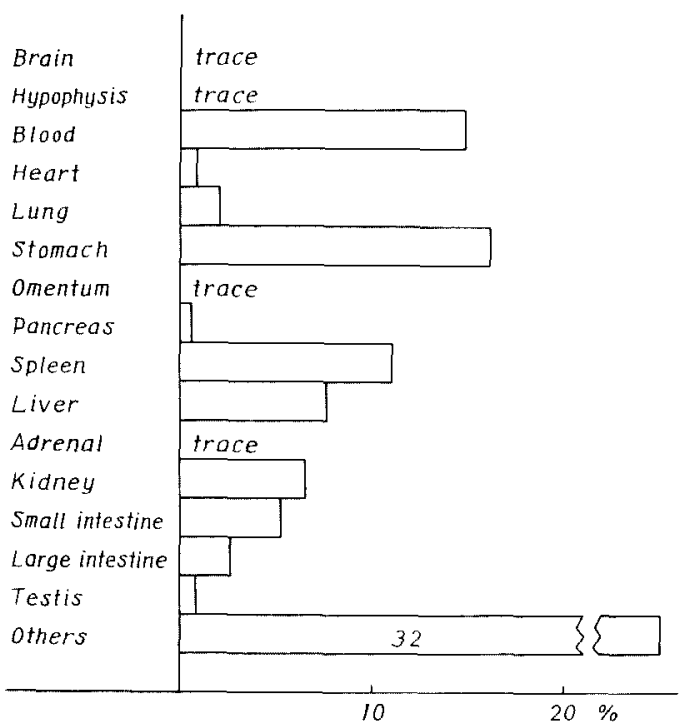

Fig. 1. The distribution rate of intraperitoneally administered $\mathrm{Na}^{1{ }^{13}} \mathrm{I}$ in various organs of normal rats.

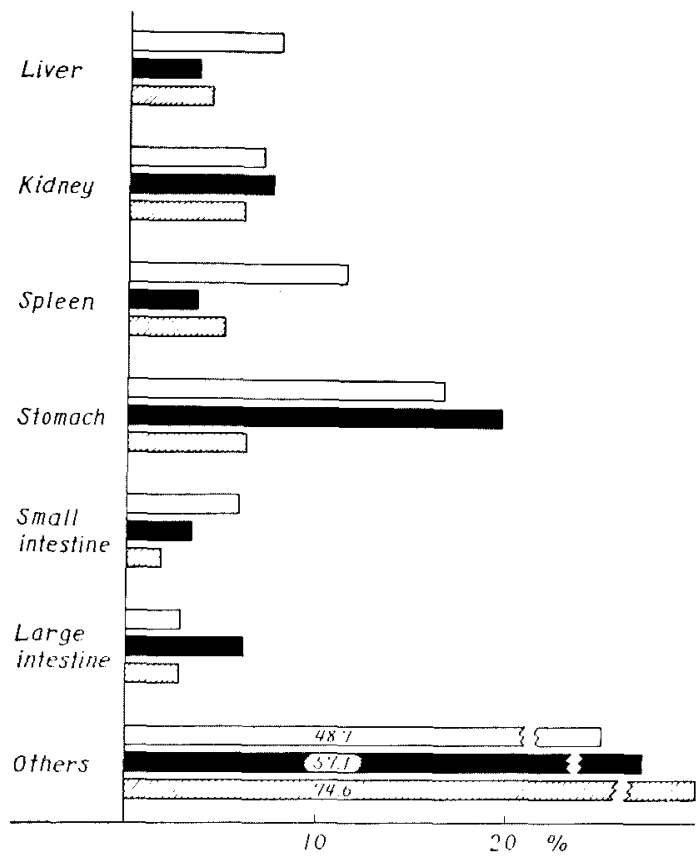

Fig. 2. The comparison between the distribution rate of $\mathrm{Na}^{131} \mathrm{I}$ in the normal rats (open bar) and the distribution rate of $\mathrm{Na}^{131}$ I labeled toxohomrone in the normal rats (shaded bar) and the distribution rate of $\mathrm{Na}^{131} \mathrm{I}$ in the liver impaired rats (hatched bar). 


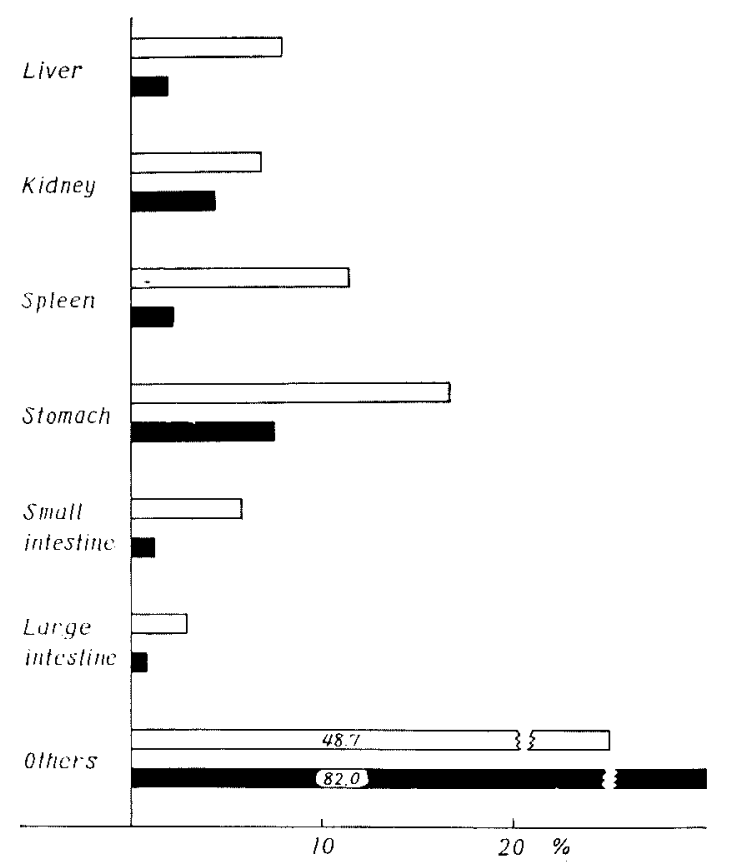

Fig. 3. The comparison of the distribution rate of $\mathrm{Na}^{131} \mathrm{I}$ in various organs between the normal rats (open bar) and those treated with toxohormone for successive 2 days (shaded bar).

in 6 organs such as liver, kidney, spleen, stomach, small intestine and large intestine was shown by "others" in Figs. 2-5. The values in each figure were the average percentages obtained from 5 cases.

The distribution rate of toxohormone labeled with $\mathrm{Na}^{131} \mathrm{I}$ in the various organs in the normal rat was found to be decreased, especially in the liver and spleen, but in the stomach and large intestine it was found to be increased, as shown in Fig. 2. On the other hand, changes in the distribution rate of $\mathrm{Na}^{131} \mathrm{I}$ in various organs in the rats which had been subjected to moderate liver impairment by intraperitoneal administration of carbon tetrachloride was found to be generally decreased.

In rats previously treated with toxohormone for successive two days, the distribution rate of intraperitoneally administered $\mathrm{Na}{ }^{131} \mathrm{I}$ in the liver and spleen was reduced to $20 \%$ of the value of untreated animals, as is shown in Fig. 3. These results suggest that disturbed liver function following carbon tetrachloride administration or a previous treatment with toxohormone induces a generalized impairment of the reticuloendothelial system.

The time course of a change in the distribution rate of $\mathrm{Na}^{131} \mathrm{I}$ labeled toxohormone in the organs of the normal rats was studied. The distribution 


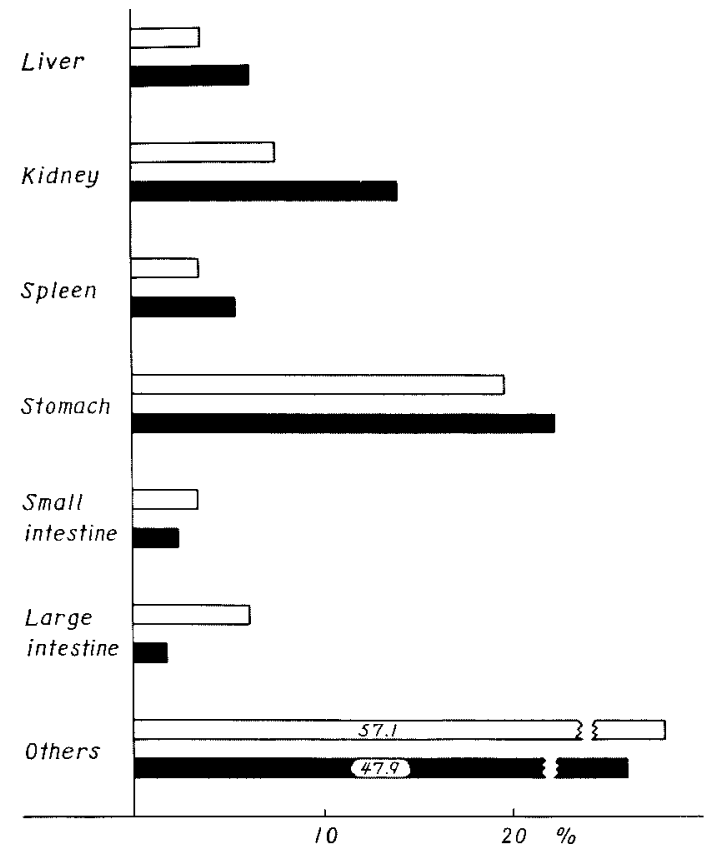

Fig. 4. The distribution rates of labeled toxohormone in various organs in $30 \mathrm{~min}$ are represented by shaded bar and those in $60 \mathrm{~min}$ by open bar.

rates in the liver, spleen, stomach and kidney in 30 minutes were higher than those 60 minutes after intraperitoneal administration of labeled toxohormone, but the distribution rate in 30 minutes in the intestine was found to be higher than that in 60 minutes, as shown in Fig. 4.

The distribution rate of $\mathrm{Na}^{131} \mathrm{I}$ labeled toxohormone in various organs, especially in the liver and kidney of the splenectomized rats, was found to be decreased as compared with that of $\mathrm{Na}^{131} \mathrm{I}$ in the same organs of the nomal rats, as shown in Fig. 5.

\section{DISCUSSION}

It is well known that toxohormone which is produced by cancer tissues is a strong inhibitor of liver catalase, but its distribution rate in different organs has not been examined. The authors, therefore, attempted to determine the distribution of toxohormone labeled with $\mathrm{Na}^{131} \mathrm{I}$ in various organs of rats.

Decrease in catalase activity of the liver after the administration of toxohormone is due to a disturbance in the intermediate process of catalase formation. Thus, the change of catalase activity in tumor bearing organisms as well as in toxohormone administered animals might be ascribed to metabolic anomalies of 


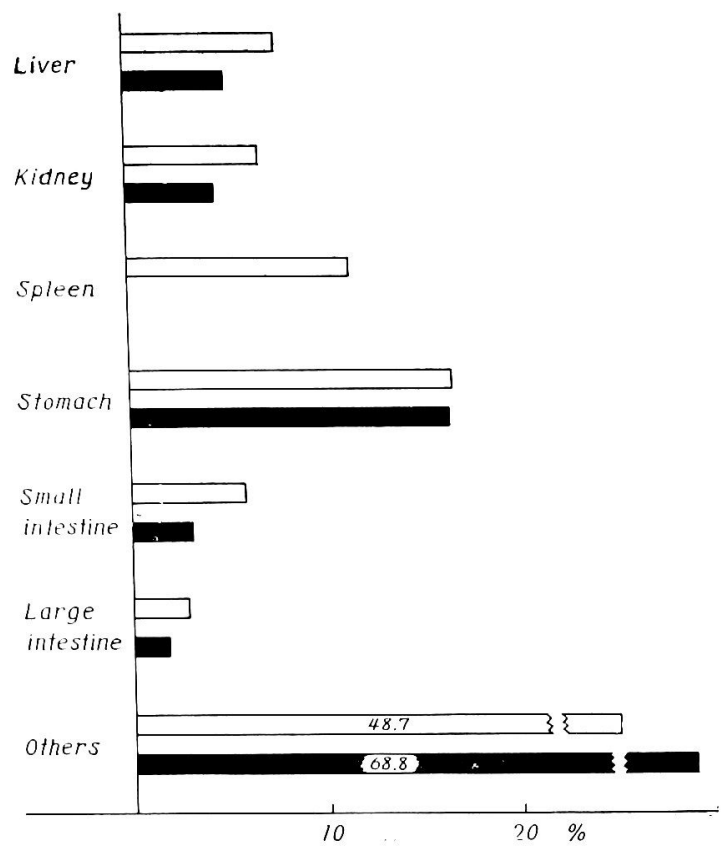

Fig. 5. The changes of distribution rate of toxohormone labeled with $\mathrm{Na}^{131} \mathrm{I}$ in the splenectomized rats (by shaded bar) as compared with normal control rats (by open bar). The experiments were done on the fourth day of splenectomy.

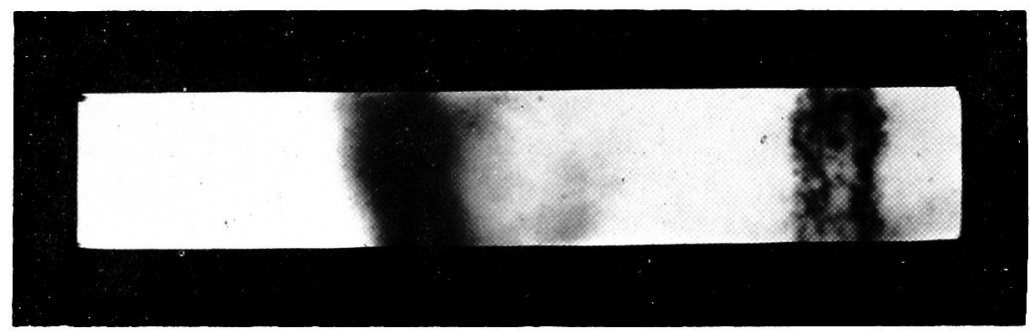

Fig. 6. The radioautogram of labeled toxohormone. Electrophoresis was performed under the condition of $12 \mathrm{~mA}, 250 \mathrm{~V}$ and for $5 \mathrm{hrs}$ in veronal buffer $(\mathrm{pH}=8.6, \lambda=0.05)$. Radioautogram was prepared by exposing the $\mathrm{x}$-ray film for 10 days. Radioactive spot to the left represents toxohormone.

heme including the increase in free protoporphyrine and decrease in ferritin in the liver, ${ }^{5}$ and decrease in serum iron levels. ${ }^{6}$

Marked atrophy of the thymus ${ }^{7}$ of the mouse was reported as one of the characteristic signs of biological changes caused by administration of toxohormone. Recently, Ralph et al. ${ }^{9}$ described that the decrease in iron levels in the serum was more sensitive than that of catalase activity when toxohormone was administered 
to the normal rats. Decrease in tryptophan pyrrolase activity, ${ }^{10}$ insufficient activity of enzymes associated with TCA cycle, inhibition of oxidative decomposition of fatty acids, decrease in non-hemin iron, and decrease in the ability of DPN synthesis ${ }^{8}$ were reported by many authors as biochemical changes in the liver of the tumor bearing organisms as well as after the treatment with toxohormone. Yamamura ${ }^{11}$ reported that the inhibition of tryptophan pyrrolase by toxohormone is due to synthetic insufficiency of a part of apoenzyme. Wartnaby ${ }^{12}$ found by tracing with colloidal radioiodinated human albumin that hepatic blood flow in patients with metastatic tumors was remarkably increased, but functional hepatic flow through the normal sinusoid remained normal. This finding suggests that a decreased distribution of labeled toxohormone in the liver and spleen is not due to decreased blood flow in these organs.

Furthermore, it is of importance to know how toxohormone affects the reticuloendothelial system in the living organism when it is administered. Norberg and Greenberg ${ }^{13}$ reported that the rate of incorporation of $\mathrm{C}^{14}$-glycine into the liver, spleen and serum proteins of the mice with transplanted lymphosarcoma was higher than that of the normal animal.

In the present study the authors obtained the result that the incorporation rates of $\mathrm{Na}^{131}$ I labeled toxohormone in the liver and spleen of the normal rats were remarkably decreased than those of $\mathrm{Na}^{131} \mathrm{I}$ in the normal rats. This result indicates that the reticuloendothelial system in the liver and spleen reacts rapidly to toxohormone.

\section{References}

1) Nakahara, W. \& Fukuoka, F. Toxohormone: a characteristic toxic substance produced by cancer tissue. Gann (Tokyo), 1949, 40, 45-69.

2) Ono, T., Umeda, M. \& Sugimura, T. Purification of toxohormone. Gann (Tokyo), $1957,48,91-100$.

3) Foss, O.P. ${ }^{131} \mathrm{I}$ as an "amplifier" in paper electrophoresis of protein solutions of low concentration. Scand. J. clin. Lab. Invest., 1959, 11, 169-171.

4) Foos, O.P. Paper electrophoresis of ${ }^{131}$ I-labeled serum protein. Sand. J. clin. Lab. Invest., 1958, 10, 418-426.

5) Ono, T., Sugimura, T. \& Ohashi, M. Effect of iron administration on the free protoporphyrine levels in erythrocyte and liver of tumor-bearing rats. Gann (Tokyo), 1959, 50, 185-188.

6) Sugimura, T., Ono, T. \& Umeda, M. Distribution of radioactive iron injected into tumor-bearing animals. Gann (Tokyo), 1957, 48, 159-168.

7) Fukuoka, F. \& Nakahara, W. Toxohormone and thymus involution in tumor bearing animals. A fourth study on toxohormone, a characteristic toxic substance produced by cancer tissue. Gann (Tokyo), 1952, 43, 55-62.

8) Ono, T. \& Tomaru, T. The toxic factor depressing DPN synthesis in tumor bearing animals. Gann (Tokyo), 1959, 50, 37-45.

9) Ralph, F.K., Mabelle, E.A. \& Thomas, A.M. Some systemic effects of toxohormone. Cancer Res., 1959, 19, 236-239. 
10) Kawachi, T., Fujii, S., Suzuki, T., Uesaki, N. \& Yamamura, Y. Effect of basic protein from tumor tissue on liver tryptophan pyrrolase activity. Gann (Tokyo), $1961,52,213-217$.

11) Yamamura, $Y$. Studies on the toxic substance in the cancer tissue. Japanese Journal of Cancer Clinics. (Ishiyakushuppan, Tokyo), 1961, 7, 85-90.

12) Wartnaby, K.M., Bouchier, I.A.O., Oope, C.E. \& Sherlock, S. Hepatic blood flow in patients with tumors of the liver. Gastroenterology, 1963, 44, 733-739.

13) Norberg, E. \& Greenberg, M.D. Incorporation of labeled glycine in the proteins of tissue of normal and tumor-bearing mice. Cancer, 1951, 4, 383-386. 